\title{
Penerapan Media Kubus Angka untuk Meningkatkan Kemampuan Mengenal Lambang Bilangan Anak TK-A Kartika IV-43 Kota Blitar
}

\author{
Mukasri
}

TK Kartika IV-43 Kota Blitar, Indonesia

Email: mukasri64@gmail.com

\section{Tersedia Online di \\ http://www.jurnal.unublitar.ac.id/i ndex.php/briliant

\begin{tabular}{l}
\hline Sejarah Artikel \\
\hline Diterima pada 7 November 2019 \\
Disetujui pada 29 November 2019 \\
Dipublikasikan pada 30 November \\
2019 Hal. 482-487
\end{tabular}

\section{Kata Kunci:}

Media Kubus, Kemampuan

Mengenal Lambang Bilangan,

TK-A

\section{DOI:}

http://dx.doi.org/10.28926/briliant. v3i4.405

\begin{abstract}
Abstrak: Penelitian ini bertujuan untuk mendiskripsikan penerapan dan peningkatan kemampuan mengenal angka/bilangan melalui media kubus angka pada Kelompok A TK Kartika IV-43 Kota Blitar. Hasil penelitian menunjukkan adanya peningkatan presentase pada hasil belajar anak. Setelah tindakan pembelajaran menggunakan media kubus angka yang dilakukan dari Siklus I sampai Siklus II. Faktor yang menyebabkan peningkatan adalah dengan penerapan media kubus angka yang menjadikan pembelajaran bermakna, dan siswa terlibat aktif. Berdasarkan hasil penelitian maka dapat disimpulkan bahwa penggunaan media kubus angka dapat meningkatkan hasil belajar kemampuan mengenal angka kelompok A TK Kartika IV-43 Kota Blitar.
\end{abstract}

\section{PENDAHULUAN}

Pendidikan Anak Usia Dini (PAUD) sebagai upaya pembinaan yang ditujukan kepada anak sejak lahir sampai dengan usia 6 tahun, dilakukan melalui pemberian rangsangan pendidikan agar pertumbuhan dan perkembangan jasmani rohani sudah siap belajar memasuki pendidikan lebih lanjut (UU No. 20/2003). Salah satu aspek perkembangan anak yang sedang berkembang pesat saat usia dini adalah kemampuan berbahasa. Menurut Zubaidah (2003:13) menyimpulkan bahwa perkembangan bahasa anak usia dini masih jauh dari sempurna, potensinya dapat dirangsang lewat komunikasi yang aktif dengan menggunakan bahasa yang baik, benar sesuai tahap perkembangan anak. Salah satu aspek bahasa yang perlu dipersiapkan dan dikembangkan adalah kemampuan mengenal angka, yang harus dikuasai oleh anak TK.

Menurut Montessori (dalam Hainstock, 2002) bahwa usia keemasan merupakan masa dimana anak mulai peka untuk menerima berbagai stimulasi dan berbagai upaya pendidikan dari lingkungannya baik disengaja maupun tidak disengaja. Pematangan fungsi-fungsi psikis terjadi pada masa tersebut sehingga anak siap merespon dan mewujudkan semua tugas-tugas perkembangan yang diharapkan muncul pada pola perilakunya sehari-hari. Rasa ingin tahu dan sikap antusias yang kuat terhadap segala sesuatu merupakan ciri yang menonjol pada 
anak usia 4-5 tahun. Anak banyak memperhatikan, membicarakan, atau bertanya tentang berbagai hal yang sempat dilihat atau didengarnya.

Pengalaman mengajar selama di TK terutama di kelompok TK A kemampuan mengenal angka mengalami kesulitan, dari 15 anak hanya 6 anak yang bisa mengenal angka. Hal ini disebabkan peneliti selama mengajar jarang sekali melakukan permaianan terutama untuk mengenal angka. Selain itu, keaktifan anak kurang, terdapat 4 anak yang sama sekali belum mengenal angka, dan yang lain untuk diajak bicara pun masih sulit sehingga anak kesulitan mengenal angka-angka yang ada di dalam kata. Jika dilihat dari sisi perkembangan, anak usia dini memang belum saatnya untuk diajari menghitung. Perkembangannya masih terpusat pada pengembangan saraf motorik. Banyak ahli yang menyarankan untuk mengembangkan kemampuan motorik anak terlebih dahulu daripada kemampuan menghitungnya. Seperti yang telah diketahui bersama bahwa kurikulum SD saat ini sudah sangat berkembang sehingga pada awal masuk SD pun, anak sudah dituntut untuk bisa membaca, menulis, dan berhitung. Sebelum anak paham operasi hitung paling sederhana (tambah dan kurang), anak-anak harus tahu konsep bilangan terlebih dahulu. Anak harus mengenal angka, baik secara lisan maupun tulisan. Hal ini berkaitan dengan kemampuan memori anak.

Berdasarkan permasalahan di atas peneliti melakukan perbaikan pembelajaran dengan menggunakan media kubus angka. Menurut Doman, permainan kubus angka adalah kotak kubus permainan yang dilakukan dengan cara menyusun kubus yang menunjukkan angka dimasukkan ke dalam tongkat secara cepat untuk memicu otak anak agar dapat menerima informasi. Bermain adalah kegiatan yang anak-anak lakukan sepanjang hari karena bagi anak. Menurut Sujiono (2009) pada dasarnya bermain memiliki tujuan utama yakni memelihara perkembangan atau pertumbuhan optimal anak usia dini melalui pendekatan bermain kreatif, interaktif dan terintegrasi dengan lingkungan bermain anak. Alat permainan menunjukkan fungsi pedagogis yang sesuai dengan usia anak TK dan taraf perkembangan, ukuran dan bentuknya sesuai dengan usia anak, aman dan tidak berbahaya, menarik baik warna maupun bentuknya, awet tidak mudah rusak dan mudah dipelihara, murah dan mudah diperoleh, tidak beracun, dapat mendorong anak untuk bereksperimen.

Penggunaan Permainan Kubus Bergambar Di Taman Kanak-kanak. Kubus bergambar adalah sebuah kubus yang ditiap sisinya terdapat gambar dan lambing bilangannya mulai dari 1-6 yang disengaja dibuat untuk permainan (Departemen Pendidikan Nasional, 2007:24). Penelitian ini peneliti menggunakan permainan kubus angka yang tempatnya seperti tongkat yang kubusnya dimasukkan ke dalam tongkat tersebut secara urut yang dibentuk dan dihias agar menarik dan dipadukan dengan kubus angka. Manfaat media kubus angka menurut Satrosudirjo (dalam Sutaryono, 1999: 26) diantaranya (1) merangsang anak belajar secara aktif, (2) timbul persaingan yang sehat antar anak, (3) melatih siswa memecahkan persoalan, (4) menumbuhkan sikap percaya dri pada anak. Tujuan penelitian ini adalah untuk mengembangkan kemampuan mengenal angka dengan menggunakan media kubus angka. Alasan dipilihnya kelompok A TK Kartika IV43 Kota Blitar sebagai subjek penelitian karena peneliti berupaya mengkoordinir kemampuan mengenal angka anak didiknya yang besar mengarah pada kegiatan 
yang bermanfaat bagi perkembangan kognitif pada tahapan perkembangan selanjutnya.

\section{METODE}

Penelitian ini adalah berbentuk Penelitian Tindakan Kelas (PTK). Menurut Arikunto (1998: 25) PTK adalah ragam penelitian pembelajaran yang berkonteks kelas dan dilaksanakan oleh pendidik untuk mencari solusi yang tepat karena permasalahan yang dihadapi dalam kegiatan pembelajaran. Penelitian ini dirancang dalam 2 siklus. Setiap siklus meliputi (1) Perencanaan; (2) Tindakan; (3) Pengamatan; dan (4) Refleksi.

Teknik pengumpulan data yang digunakan dalam penelitian ini adalah observasi, dokumentasi, dan catatan lapangan. Observasi dilakukan pada saat kegiatan pembelajaran dan juga melihat hasil kegiatan baik yang dilakukan untuk observasi aktivitas guru, aktivitas anak, penilaian sikap, pengetahuan dan keterampilan dalam mengenal angka selama kegiatan pembelajaran dengan menerapkan media kubus angka. Dokumentasi dalam penelitian ini adalah teknik pengumpulan data informasi perkembangan anak melalui foto kegiatan pada saat penerapan media kubus angka pada kelompok A TK Kartika IV-43 Kota Blitar. Catatan lapangan digunakan untuk mengetahui kejadian yang terjadi selama pembelajaran dengan menerapkan media kubus angka. Isi catatan berupa suasana kelas, interaksi guru dan anak, serta kejadian-kejadian yang muncul yang tidak direncanakan.

Analisis data yang dapat digunakan adalah Reduksi Data yaitu suatu proses pengambilan data melalui tahapan-tahapan dalam penelitian. Semua kegiatan direduksi,dan semua data yang terkumpul dan dirangkum. Penyajian data yaitu merupakan pengorganisasian hasil reduksi disusun secara narasi dari informasi untuk memberikan kemungkinan terjadi kesimpulan atau perubahan. Sedangkan penarikan kesimpulan yaitu tahap akhir analisis data untuk menjelaskan secara tingkat makna data penelitian.

\section{HASIL}

\section{Siklus I}

Hasil aktivitas guru pada siklus I pertemuan 1 dan 2 terjadi kenaikan dari kriteria cukup yaitu $55 \%$ menjadi baik dengan presentase $75 \%$. Artinya ada 1 dari 6 langkah kegiatan guru yang belum dilaksanakan dengan baik. Sedangkan hasil aktivitas anak pada siklus 1 pertemuan 1 dan 2 terjadi kenaikan dari presentase keberhasilan 50\% menjadi 65\%. Artinya terdapat 2 dari 6 langkah kegiatan anak yang belum dilaksanakan dengan baik.

Hasil penilaian sikap pada siklus 1 pertemuan 1 dan 2 terjadi kenaikan. Pada siklus 1 pertemuan 1 terdapat 8 anak yang belum tuntas dan 7 anak yang sudah tuntas dan presentase ketuntasan sebesar 46,6\% dengan kriteria kurang sekali. Pada pertemuan 2 terjadi kenaikan yaitu sebanyak 9 anak telah tuntas dan 6 anak belum tuntas. Presentase keberhasilan pada pertemuan 2 sebesar $60 \%$ dengan kriteria cukup. Hasil penilaian pengetahuan pada siklus 1 pertemuan 1 dan 2 terjadi kenaikan. Pada pertemuan 1 hanya 5 anak yang tuntas dengan presentase $33 \%$ dan pada pertemuan 2 terjadi kenaikan dengan jumlah anak yang tuntas yaitu 6 anak dengan persentase 40\%. Hasil penilaian keterampilan pada siklus 1 pertemuan 1 dan 2 terjadi kenaikan. Pada siklus 1 pertemuan 1 terdapat 12 anak 
yang belum tuntas dan hanya 3 anak yang sudah tuntas dan presentase ketuntasan sebesar 20\% dengan kriteria kurang sekali. Pada pertemuan 2 terjadi kenaikan yaitu sebanyak 6 anak telah tuntas dan 9 anak belum tuntas. Presentase keberhasilan pada pertemuan 2 sebesar $40 \%$ dengan kriteria kurang kurang sekali.

\section{Siklus II}

Hasil aktivitas guru pada siklus 2 pertemuan 1 dan 2 telah mencapai $100 \%$. Artinya langkah-langkah yang harus dilakukan guru telah secara lengkap dilaksanakan. Sedangkan hasil aktivitas anak pada siklus 2 pertemuan 1 dan 2 terjadi kenaikan dari presentase keberhasilan 83,3\% menjadi 100\%. Artinya pada pertemuan 2, seluruh aktivitas yang harus dilakukan anak telah dilaksanakan dengan baik.

Hasil penilaian sikap pada siklus 2 pertemuan 1 dan 2 terjadi kenaikan. Pada siklus 2 pertemuan 1 terdapat 3 anak yang belum tuntas dan 12 anak yang sudah tuntas dan presentase ketuntasan sebesar $80 \%$ dengan kriteria baik. Pada pertemuan 2 terjadi kenaikan yaitu sebanyak 14 anak telah tuntas dan hanya 1 anak yang belum tuntas. Presentase keberhasilan pada pertemuan 2 sebesar 93\% dengan kriteria sangat baik. Hasil penilaian pengetahuan pada siklus 2 pertemuan 1 dan 2 terjadi kenaikan. Pada pertemuan 1 sebanyak 9 anak tuntas dengan presentase $60 \%$ dan pada pertemuan 2 terjadi kenaikan dengan jumlah anak yang tuntas yaitu 12 anak dengan persentase $80 \%$. Sedangkan hasil keterampilan pada siklus 2 pertemuan 1 dan 2 terjadi kenaikan. Pada siklus 2 pertemuan 1 terdapat 12 anak yang tuntas dan hanya 3 anak yang belum tuntas dan presentase ketuntasan sebesar $80 \%$ dengan kriteria baik. Pada pertemuan 2 terjadi kenaikan yaitu sebanyak 13 anak telah tuntas dan hanya 2 anak belum tuntas. Presentase keberhasilan pada pertemuan 2 sebesar $87 \%$ dengan kriteria sangat baik.

\section{PEMBAHASAN}

\section{Penerapan Media Kubus Angka untuk Meningkatkan Kemampuan Mengenal Angka pada Kelompok A TK Kartika IV-43 Kota Blitar}

Penggunaan media kubus angka untuk meningkatkan kemampuan mengenal angka pada Kelompok A TK Kartika IV-43 Kota Blitar dilaksanakan sesuai dengan baik. Penelitian dilaksnakan dalam 2 siklus, masing-masing siklus terdiri dari 2 pertemuan.

Keberhasilan penerapan media kubus angka pada Kelompok A TK Kartika IV-43 Kota Blitar dapat dilihat dari catatan lapangan pada setiap pertemuan. Anak yang pada awalnya sulit dikondisikan dan ramai sendiri menjadi tertib dan dapat menyelesaikan pembelajaran dengan baik. Anak merasa mendapat pengalaman belajar baru yang menyenangkan sehingga anak antusias dalam belajar. Hal itu didukung dari hasil penilaian sikap, pengetahuan dan keterampilan disetiap pertemuan pada siklus 1 dan siklus 2 yang mengalami peningkatan.

Peningkatan ini terjadi karena saat guru menemui kekurangan pada saat pembelajaran, guru langsung melakukan refleksi dan melakukan perbaikan pada pertemuan selanjutnya. Sehingga penggunaan media kubus angka dalam proses pembelajaran mengenal angka dapat benjalan dengan baik dan diperoleh hasil yang maksimal. Dari fakta-fakta tersebut disimpulkan bahwa media kubus angka dapat meningkatkan kemampuan mengenal angka kelompok A TK Kartika IV-43 Kota Blitar. 


\section{Peningkatan Kemampuan Mengenal Angka melalui Media Kubus Angka pada Kelompok A TK Kartika IV-43 Kota Blitar}

Penelitian tentang peningkatan kemampuan mengenal angka melalui media kubus angka diperoleh dari data pada siklus 1 dan siklus 2 yang mengalami peningkatan. Pada siklus 1 diperoleh hasil penilaian sikap anak pada pertemuan 1 dan pertemuan 2, jumlah anak yang tuntas 8 anak dengan presentase ketuntasan 53\% meningkat menjadi 10 anak dengan presentase ketuntasan 67\%. Penilaian pengetahuan anak pada siklus 1 pertemuan pertama dan kedua masih kurang yaitu dengan presentase ketuntasan $33 \%$ atau hanya 5 anak yang tuntas dan meningkat menjadi $40 \%$ atau hanya 6 anak yang tuntas. Sedangkan penilaian keterampilan pada siklus 1 masing sangat rendah. Presentase ketuntasan pada pertemuan pertama hanya $20 \%$ dan pada pertemuan kedua meningkat menjadi $40 \%$. Kekurangan-kekurangan pada siklus 1 akan terus diperbaiki pada siklus 2 agar kegiatan pembelajaran dengan menggunakan media kubus angka dapat berjalan dengan baik untuk meningkatkan kemampuan mengenal angka dapat tercapai dengan maksimal sesuai dengan presentase yang diharapkan.

Perbaikan yang dilakukan pada siklus 2 mengalami peningkatan. Pada penilaian sikap anak, presentase ketuntasan pertemuan pertama sebesar $80 \%$ meningkat pada pertemuan kedua menjadi 93\% dengan kriteria sangat baik. Sedangkan pada penilaian pengetahuan, presentase ketuntasan pada pertemuan pertama sebesr $60 \%$ meningkat menjadi $80 \%$ pada pertemauan kedua dengan kriteria baik. Dan pada penilaian keterampilan pertemuan pertama presentase kekuntasan sebesar $80 \%$ meningkat menjadi $87 \%$ dengan kriteria baik. Hal tersebut menunjukkan bahwa sebagian besar anak telah tuntas dalam belajar.

Peningkatan pada setiap pertemuan terjadi karena dalam kegiatan mengenal angka dilakukan menggunakan media sehingga dapat menarik perhatian anak. Berdasarkan uraian tersebut disimpulkan bahwa media kubus angka dapat meningkatkan kemampuan mengenal angka pada kelompok A TK Kartika IV-43 Kota Blitar.

\section{KESIMPULAN}

Berdasarkan penelitian yang telah dilakukan di TK Kartika IV-43 Kota Blitar dapat disimpulkan bahwa (1) Penerapan permainan Kubus Angka dalam meningkatkan kemampuan mengenal angka kelompok TK A Kartika IV-43 Kota Blitar telah dilaksanakan dengan baik dan sesuai dengan RPPH. Hal ini terbukti dari hasil pengamatan aktivitas guru siklus 1 dan siklus dua mengalami peningkatan hingga mencapai $100 \%$, dan (2) penerapan permainan kubus angka dapat meningkatkan kemapuan mengenal angka kelompok TK A Kartika IV-43 Kota Blitar. Hal tersebut dapat dilihat dari peningkatan presentase ketuntasan penilaian sikap, pengetahuan dan keterampilan yang dilaksanakan disetiap pertemuan pada siklus 1 dan siklus 2 .

\section{SARAN}

Berdasarkan penelitian maka dapat diajukan saran-saran guna meningkatkan serta membangun kualitas pembelajaran di TK Kartika IV-43 Kota Blitar sebagai berikut, (1) bagi guru, yaitu Guru hendaknya dapat mengembangkan aspek-aspek pegembangan anak TK dengan melalui berbagai 
permainan agar anak dapat aktif dan kreatif. Hasil penelitian ini dapat mendorong guru untuk dapat melaksanakan pembelajaran model permainan, (2) bagi anak, yaitu dengan model permainan anak dapat mengembangkan kreativitas, imajinasi dalam berbagai bidang kegiatan, dan (3) bagi sekolah, yaitu dari hasil penelitian dapat dijadikan bahan referensi dan masukan untuk bisa dilanjutkan pada guru untuk mencoba melaksanakan kegiatan pembelajaran melalui berbagai permainan.

\section{DAFTAR RUJUKAN}

Arikunto, Suharsimi. 1998. Prosedur Penelitian Suatu Pendekatan Praktik. Jakarta: PT Rineka Cipta.

Arifin, Zaenal. 2009. Evaluasi Pembelajaran. Bandung: PT Remaja Rosdakarya

Departemen Pendidikan Nasional. 2003. Didaktik metodik di Taman KanakKanak. Jakarta: Depdiknas.

Depdiknas. 2007. Pedoman Pendidikan Berorientasi Kecakapan Hidup Taman Kanak-Kanak (TK). Jakarta: Direktorat Jenderal Pendidikan Dasar dan Menengah

Hainstock, Elizabeth G. 2002. Montessori untuk Anak Prasekolah. Jakarta: Pustaka Delapratasa.

Sujiono, Yuliani Nurani. 2009. Konsep Dasar Pendidikan Anak Usia Dini. Jakarta: PT Indeks

Sutaryono. 1999. Efektivitas Penggunaan Kartu Terhadap Hasil Belajar Siswa. Skripsi. (Online), Yogyakarta: UNY diakses pada 21 September 2018. Zubaidah, Eny. 2003. Pengembangan Bahasa Anak Usia Dini. Yogyakarta: UNY 